\author{
JÓZEF KOREDCZUK \\ ORCID: 0000-0002-3471-586X \\ Uniwersytet Wrocławski \\ jozef.koredczuk@uwr.edu.pl
}

\title{
Stosunek biskupa Ignacego Krasickiego do reform polityczno-prawnych w Polsce doby stanisławowskiej
}

Postać Ignacego Krasickiego jest powszechnie znana, przede wszystkim jako poety, literata. Trochę mniej są rozpowszechnione jego poczynania jako administratora kościelnego, najpierw biskupa warmińskiego, a później arcybiskupa gnieźnieńskiego. Najmniej natomiast jest znany jego stosunek do zmian politycznych w Polsce w okresie panowania Stanisława Augusta Poniatowskiego.

Ignacy Błażej Franciszek Krasicki (herbu Rogala) urodził się 3 lutego 1735 roku w Dubiecku, nad Sanem. Miał czterech braci, spośród których trzech podobnie jak i on zostało duchownymi. W 1754 roku, po ukończeniu seminarium misjonarzy przy kościele św. Krzyża w Warszawie przyjął święcenia kapłańskie ${ }^{1}$. Po powrocie w drugiej połowie 1761 roku ze studiów w Rzymie związał się ze stronnictwem saskim w Polsce, przede wszystkim reprezentowanym przez Franciszka Salezego Potockiego, podejmując działalność agenta politycznego. W tej roli uczestniczył w otwarciu sejmu w 1762 roku i reasumpcji trybunału w Piotrkowie. Po śmierci w 1763 roku Augusta III przeszedł do grona bliskich współpracowników Stanisława Poniatowskiego ${ }^{2}$.

Po wyborze 7 września 1764 roku Stanisława Augusta Poniatowskiego na króla Polski został jego kapelanem. W tym między innymi charakterze podczas nabożeństwa koronacyjnego władcy wygłosił niczym szczególnym niewyróżniające się kazanie, aczkolwiek dyskretnie i z przejęciem poruszył w nim potrzebę

1 Z. Goliński, Kalendarz życia i twórczości Ignacego Krasickiego, Poznań 2011, s. 74-75.

2 Z. Goliński, Krasicki Ignacy Błażej Franciszek h. Rogala, [w:] Polski Słownik Biograficzny, t. 15. Kozłowska Zofia - Kubacki Stanisław, Wrocław-Warszawa-Kraków 1970, szp. 144-145. 
wzmocnienia władzy w państwie, sprawiedliwości i w ogóle reform ${ }^{3}$. Stał się jednym z najwierniejszych stronników króla, robiąc szybką i błyskotliwą karierę.

W 1765 roku został prezydentem Trybunału Głównego Koronnego prowincji małopolskiej ${ }^{4}$. Był to trybunał działający na nowych zasadach, po tym, jak go zreformowano na sejmie koronacyjnym w 1764 roku. Celem wspomnianej reformy, w wyniku której podzielono Trybunał Koronny na dwie jurysdykcje, wielkopolską i małopolską, było zmniejszenie powagi trybunałów, które za Augusta III wyszły z zakresu swoich kompetencji i zaczęły rozpościerać polityczną władzę ${ }^{5}$. Z pracami Trybunału Koronnego (ale w Piotrkowie) miał okazję się zapoznać Krasicki już wcześniej, przyglądając się jego obradom w 1761 lub 1762 roku. W 1763 roku wysuwano nawet jego kandydaturę na prezydenta Trybunału ${ }^{6}$. Wcześniej był kustoszem kapituły lwowskiej, ponieważ to kapituła miała prawo do wskazania deputata na to stanowisko. Jako prezydent usiłował spełnić oczekiwania króla Stanisława Augusta, który przede wszystkim pragnął usprawnić organizację pracy Trybunału oraz doprowadzić do tego, by jego wyroki były bardziej sprawiedliwe. Z inicjatywy Krasickiego w tym celu został uchwalony rodzaj wewnętrznego regulaminu - Monita secreta, dyscyplinujący deputatów podczas sesji. Starał się on także ograniczyć ceremoniał trybunalski ${ }^{7}$. W trakcie sesji lwowskiej, wiosną 1765 roku Krasicki, pragnąc podnieść poziom palestry i sądownictwa, zabiegał o dokonanie przekładu słynnego dzieła Causes célèbres et intéressantes, którego autorem był François Gayot de Pitaval. Stanowiło ono opis najważniejszych procesów kryminalnych Pitavala, ,przykłady, wnioski i wywody z niego — zdaniem Krasickiego

3 M. Piszczkowski, Ignacy Krasicki. Monografia literacka, Kraków 1975, s. 21.

${ }^{4}$ Por. I. Tretiak, Ignacy Krasicki jako prezydent trybunatu, Kraków 1895.

5 A. Kraushar, Książe Repnin a Polska w pierwszem czteroleciu panowania Stanisława Augusta (1764-1768), t. 2, Kraków 1898, s. 109, przyp. 1.

${ }^{6}$ Miało to związek ze śmiercią Macieja Mostowskiego, proboszcza piotrkowskiego, z którym to stanowiskiem łączyła się także funkcja prezydenta Trybunału Koronnego; Z. Goliński, Kalendarz..., s. 76-77; S. Achremczyk, Nowa biografia Ignacego Krasickiego, „Komunikaty Mazursko-Warmińskie" 1980, nr 2, s. 259; P.M. Pilarczyk, Doświadczyński przed Trybunatem. Twórczość Ignacego Krasickiego w świetle historii prawa, „Pamiętnik Literacki” 118, 2017, z. 3, s. 92-93. Krasicki odegrał także niepochlebną rolę jako wysłannik biskupa krakowskiego Kajetana Sołtyka w przekupieniu deputatów Trybunału Lubelskiego w 1759 roku, którzy rozpatrywali znany spór między kanclerzem wielkim koronnym Janem Małachowskim i Janem Duninem Karwickim a marszałkiem nadwornym koronnym Jerzym Augustem Wandalinem Mniszechem i wspierającym go Kajetanem Sołtykiem o dobra pochodzące z podziału ordynacji ostrogskiej; Z. Goliński, Kalendarz..., s. 52-54, 57-58.

${ }^{7}$ K. Gombin, Lwów w ceremoniale Trybunału Koronnego prowincji małopolskiej, „Annales Universitatis Mariae Curie-Skłodowska. Sectio L" 8, 2010, nr 2, s. 36-38. We wrześniu 1765 roku na Krasickiego jako prezydenta Trybunału miał miejsce napad, jego sprawca Antoni Marszycki został za to skazany na karę dolnej wieży na jeden rok i sześć tygodni; B. Grużewski, Napad na prezydenta Trybunału (Rok 1765). Przyczynek biograficzno-obyczajowy z drugiej połowy XVIII wieku, [w:] Pamiętnik trzydziestolecia pracy naukowej prof. dr. Przemysława Dąbkowskiego, Lwów 1927, s. 295-314. 
— były potrzebne palestrze polskiej jako dobre oryginały, wzory"8. Sam Krasicki o pracy w trybunale pisał: „Odetchnąć momentu nie mogę [...] w takiem jestem jarżmie, że z szyji na najmniejszy punkt czasu złożyć nie mam sposobności”.9.

Zbyt długo Krasicki prezydentem Trybunału Małopolskiego nie pozostał, gdyż pod koniec 1766 roku objął, po śmierci biskupa Adama Stanisława Grabowskiego, jedno z najważniejszych polskich biskupstw — w Lidzbarku Warmińskim ${ }^{10}$. Pozytywnie o kandydaturze Krasickiego na stanowisko biskupa warmińskiego wypowiedział się także ksiądz Stanisław Konarski, były prowincjał zakonu pijarów $^{11}$. Z biskupstwem tym związane było zajmowane w senacie Rzeczypospolitej szóste miejsce, które Krasicki objął, składając 2 stycznia 1767 roku na sesji senatorów i ministrów stosowną przysięgę ${ }^{12}$. Zdaniem Zbigniewa Golińskiego ,położone na uboczu biskupstwo warmińskie mogło stać się zawsze — w miarę potrzeby — schronieniem przed obowiązkami życia publicznego"13. Inaczej na sprawę obsady biskupstwa warmińskiego patrzył król Stanisław August, który wskazując Krasickiego na ten urząd, z którym związane było także stanowisko prezesa ziem pruskich, odgrywającego znaczącą rolę, widział w nim jeden $\mathrm{z}$ elementów budowy silnego stronnictwa regalistycznego w Prusach, popierającego jego plany ${ }^{14}$. Aleksy Husarzewski (komisarz królewski Rzeczypospolitej w Gdańsku), który wstępnie badał ewentualność uzyskania koadiutorii warmińskiej dla Krasickiego, w liście do króla z 15 kwietnia 1766 roku na ten temat pisał: „Wyobrażam sobie, że prowincja ta, jedna z pereł Korony WKMci, uwzględniona jest w planach generalnej reformy Królestwa, jaką WKMość zamierzasz przeprowadzić. [...] Jakaż to byłaby dla WKMci ulga, mieć tu osobę tak zręczną i tak oddaną jak ksiądz Krasicki!"'15.

Krasicki już wcześniej został wciągnięty w wir życia politycznego w Polsce, jako bowiem sekretarz interreksa, prymasa Władysława Aleksandra Lubieńskiego, miał okazję się przekonać, czym jest polityka, podczas elekcji poprzedzającej

${ }^{8}$ M. Piszczkowski, op. cit., s. 23; Z. Goliński, Kalendarz..., s. 125-126.

9 Z. Mayer, Wizerunek Trybunatu Koronnego. Studjum prawno-obyczajowe, Lwów 1929, s. $36-37$.

${ }^{10}$ Wcześniej powierzono mu wiele różnych stanowisk kościelnych, był między innymi kanonikiem kijowskim i przemyskim, proboszczem katedralnym przemyskim, koadiutorem opactwa wąchockiego, kapelanem królewskim, kustoszem katedry we Lwowie, proboszczem w Kodniu. By zostać biskupem warmińskim, Krasicki musiał kupić kanonię warmińską, której został prałatem kantorem oraz zostać koadiutorem na biskupstwo warmińskie. Oprócz biskupstwa warmińskiego zaoferowano mu także do wyboru biskupstwo przemyskie i żmudzkie.

11 W. Maciąg, Życie Ignacego Krasickiego. Zapisy i domysty, Warszawa 1984, s. 145-146.

12 J.I. Kraszewski, Krasicki. Życie i dzieła. Kartka z dziejów literatury XVIII wieku, Warszawa 1879, s. 94.

13 Z. Goliński, Ignacy Krasicki, Warszawa 1979, s. 179.

14 J. Dygdała, Życie polityczne Prus Królewskich u schytku ich związku z Rzeczapospolita w XVIII wieku, Warszawa-Poznań-Torun 1984, s. 173; idem, Adam Stanisław Grabowski (16981766). Biskup, polityk, mecenas, Olsztyn 1994, s. 92.

15 Z. Goliński, Kalendarz..., s. 148. 
wybór Stanisława Poniatowskiego na króla Polski. W jej trakcie prymas Łubieński zaczął deklarować się jako stronnik Czartoryskich, którzy przy okazji sejmu konwokacyjnego 1764 roku chcieli przeforsować nie tylko swojego kandydata na tron, ale przeprowadzić również pewne reformy ustrojowe.

Jedną z pierwszych i najdłużej kontynuowanych form zaangażowania Krasickiego w życie polityczne Rzeczypospolitej było założenie przez niego wraz z Franciszkiem Bohomolcem i Adamem Kazimierzem Czartoryskim w 1765 roku czasopisma „Monitor”. Inicjatorem jednakże jego powstania był król Stanisław August Poniatowski, który udzielił także wsparcia przy jego powstaniu. Redagowane było ono na wzór angielskiego pisma „The Spectator”. Warto podkreślić, że to właśnie w pierwszym okresie, decydującym o kształcie pisma, redagował „Monitora" Krasicki, będąc między innymi autorem jego planu tematycznego, lansującego reformy państwa. Zamieścił w nim także wiele swoich publikacji ${ }^{16}$. Pismo, mimo że zasadniczym jego celem była poprawa obyczajów i moralności społeczeństwa, popierało i promowało tolerancję religijną oraz krytykowało feudalizm szlachecki i magnacki, wspierało zaś mieszczaństwo i chłopstwo. W „Monitorze” Krasicki domagał się likwidacji nierządu politycznego w Rzeczypospolitej i jego skutków ujemnych zarówno dla samego organizmu państwowego, jak i moralności publicznej i jednostkowej. Domagał się także uznania człowieka w pańszczyźnianym chłopie. Było to najważniejsze czasopismo społeczno-polityczne polskiego oświecenia. Przetrwało do roku $1785^{17}$.

W „Monitorze” Krasicki odnosił się także niekiedy do kwestii prawnych obowiązujących w Rzeczypospolitej. Między innymi w numerach z 21 i 24 sierpnia 1765 roku nawiązał do kwestii indygenatu, podkreślając, że jego nadawanie może stać się zachętą do osiedlania się zasobnych cudzoziemców w Polsce, przyczynić się do ożywienia handlu i stworzenia warunków rozwoju przemysłu. Natomiast wzbranianie cudzoziemcom zakupu dóbr ziemskich powodowało słabe zaludnienie i ubóstwo kraju ${ }^{18}$. Z kolei w numerach z lipca, sierpnia i września 1768 roku odniósł się do dzieła Monteskiusza $O$ duchu praw, uznając, że wybór ten w ówczesnej sytuacji politycznej Polski jest szczególnie aktualny ${ }^{19}$.

Jako biskupowi nieobojętna była mu sprawa praw dyzunitów i dysydentów, która wywołała ostry spór w Rzeczypospolitej w 1767 roku. Król Stanisław August osobiście prosił Krasickiego, by przybył na posiedzenie senatu, które w tej sprawie miało się odbyć 25 maja 1767 roku $^{20}$. Mimo mocnych nacisków ze strony

16 Por. W. Aleksandrowska, Problemy monitorowego autorstwa Krasickiego. Z warsztatu bibliografa „Monitora”, „Pamiętnik Literacki” 90, 1999, z. 1, s. 153-166; I. Chrzanowski, Krasicki jako autor Monitora z roku 1772, „Pamiętnik Literacki” 3, 1904, z. 2, s. 281-294.

17 M. Klimowicz, Oświecenie, Warszawa 1975, s. 81, 85, 88-90; R. Wołoszyński, Ignacy Krasicki a myśl oświecenia, „Pamiętnik Literacki” 61, 1970, z. 2, s. 22.

18 Z. Goliński, Kalendarz..., s. 129-130.

19 Ibidem, s. 271-285.

${ }^{20}$ List Stanisława Augusta do Krasickiego z dnia 8 kwietnia 1767 roku; ibidem, s. 222-223. 
Nikołaja Repnina, by tego nie robił, 21 sierpnia 1767 roku — wraz z innymi pięcioma biskupami $^{21}$ — przystąpił do konfederacji szlachty katolickiej zawiązanej w Radomiu pod laską Karola Radziwiłła „Panie Kochanku”. Uczynił to jednak z zastrzeżeniem wierności królowi, do detronizacji którego konfederaci także chcieli doprowadzić ${ }^{22}$.

Na sejmie nadzwyczajnym, który zebrał się w tej sprawie jesienią 1767 roku, Krasicki znalazł się między przysłowiowym „młotem a kowadłem”. Z jednej strony, jako prezesowi Stanów Ziem Pruskich, nieobojętne było mu stanowisko bardzo aktywnych na tym sejmie posłów Prus Królewskich, którzy bronili swoich przywilejów i praw. Posłowie i senatorowie pruscy, po oddzieleniu się od Wielkopolski, kilkakrotnie spotkali się i obradowali w tej sprawie w mieszkaniu Krasickiego. Stanowczo sprzeciwili się wówczas żądaniom rosyjskim równouprawnienia religijnego dysydentów oraz wyłonienia delegacji sejmowej, która zamiast sejmu miałaby się tą sprawą zając ${ }^{23}$. Sprawiali tym samym kłopot Repninowi i królowi, z którymi także, z drugiej strony, nie zgadzał się Krasicki, unikając jednakże ostrego konfliktu z nimi. Według Józefa Tretiaka był to pierwszy i ostatni sejm, na którym Krasicki występował jako senator Rzeczypospolitej ${ }^{24}$. Również gdy w następstwie przyjętej uchwały sejmowej powołano do życia konfederację barską, na radzie senatu w dniu 24 marca 1768 roku, na której miano zadecydować, czy wezwać wojska rosyjskie przeciw konfederatom, był jednym z 18 senatorów, który wystąpił w ich obronie. Ostatecznie jednakże pod wpływem pogróżek Repnina i perswazji Stanisława Augusta ustąpił z zajmowanego stanowiska ${ }^{25}$.

Na sejmie w kwietniu 1768 roku - po wywiezieniu przez Repnina liderów konfederacji radomskiej (biskupa krakowskiego Kajetana Sołtyka, biskupa kijowskiego Andrzeja Załuskiego, hetmana polnego koronnego Wacława Rzewuskiego i jego syna Seweryna, starostę dolińskiego) do Kaługi - Krasicki jako członek senatu bardzo mocno wystąpił przeciwko temu gwałtowi i wniósł, aby sejm, dopóki wywiezieni jego reprezentanci nie powrócą, nie podejmował żadnych czynności. Również królowi Stanisławowi Augustowi doradzał, by zawiesić

${ }^{21}$ Byli to: biskup kujawski Antoni Ostrowski, biskup płocki Szeptycki, biskup przemyski Młodziejowski, biskup kijowski Załuski i biskup inflancki Giedroyć. Repnin zagroził im, że jeżeli nie wycofają swojego akcesu do konfederacji, nie zostaną dopuszczeni do obrad senatu; ibidem, s. $239,244$.

22 K. Stasiewicz, Obywatelskie dylematy uśmiechniętego biskupa Ignacego Krasickiego, „Komunikaty Mazursko-Warmińskie" 2018, nr 1, s. 130-131.

23 Przedstawiciele Prus, po oddzieleniu się od Wielkopolski, w tej sprawie spotkali się i obradowali w mieszkaniu Krasickiego. Dnia 17 października 1767 roku pod prezydencją Krasickiego opowiedzieli się przeciwko zmianie aktu limity sejmu na rzecz delegacji; A. Kraushar, op. cit., s. 33-34; J. Dygdała, Życie..., s. 221-223; Z. Goliński, Kalendarz..., s. 246.

24 J. Tretiak, Ignacy Krasicki. Charakterystyka w ramach szkicu biograficznego, „Biblioteka Warszawska" 4, 1901, s. 489.

${ }^{25}$ K. Stasiewicz, op. cit., s. 131; M. Parkitny, O genezie „Myszeidy” Ignacego Krasickiego, „Pamiętnik Literacki” 89, 1998, z. 1, s. 63-64; Z. Goliński, Krasicki..., szp. 145. 
obrady sejmu do czasu powrotu porwanych senatorów. Kiedy jego wniosek został odrzucony, oświadczył: „Kiedy nie można wolnie radzić na sesjach, lepiej jest na nie nie chodzić i nie być przymuszonym obcej przemocy słuchać”. Następnie wraz z innymi patriotami zasiadającymi w sejmie opuścił salę obrad, a potem stolicę. Przestał także w związku z tym przychodzić na obrady sejmu, by do gwałtów czynionych przez Moskwę nie przykładać ręki ${ }^{26}$. Co do wypowiedzi Krasickiego na wspomnianym sejmie nasuwają się wątpliwości, nie są one bowiem odnotowane w diariuszu sejmowym. Nie potwierdził ich także Józef Wybicki, który był posłem na sejm z tej samej prowincji co Krasicki ${ }^{27}$.

W trudnych latach konfederacji barskiej najłatwiej było opowiedzieć się za jedną ze stron konfliktu — królem albo konfederatami. Widząc niejednoznaczną wartość tego zrywu, pogmatwanie ideowe, polityczne i narodowe całego przedsięwzięcia, Krasicki odmówił mu swojej uwagi i nie czując się na siłach do wzięcia udziału w akcji po stronie żadnego z walczących obozów, po prostu wyjechał z Polski do Francji ${ }^{28}$.

Od czasów konfederacji barskiej, a szczególnie po pierwszym rozbiorze, w wyniku którego ziemie biskupstwa warmińskiego znalazły się poza granicami Polski, polityczne zapatrywania Krasickiego i Stanisława Augusta Poniatowskiego zaczęły się coraz bardziej rozchodzić ${ }^{29}$. Krasicki jako biskup, którego stolica diecezji po pierwszym rozbiorze znalazła się pod zaborem pruskim, przestał zasiadać w senacie Rzeczypospolitej ${ }^{30}$. Praktycznie po roku 1773 nie brał udziału w sprawach politycznych. Stało się tak wbrew oczekiwaniom króla, który był niezadowolony z tego, że Krasicki nie służył mu i jego sprawom oraz nie uświetniał jego panowania swoimi pismami, tak jak to czynili inni, chociażby sekretarz i szambelan królewski Stanisław Trembecki ${ }^{31}$. Krasicki nie bardzo wierzył, że można uratować Polskę jako państwo ${ }^{32}$.

W reakcji na pierwszy rozbiór Polski w 1772 roku, przebywając wówczas poza granicami kraju, wystosował list do kapituły warmińskiej we Fromborku, w którym zalecał jej członkom wierność Rzeczypospolitej, a to, w jakim stopniu mają być lojalni wobec Prus, pozostawił do rozważenia ich własnym sumieniom.

26 J. Zaleski, Panowanie Stanisława Augusta do czasu Sejmu Czteroletniego, Poznań-Kraków 1887, s. 144-145; K. Maksymowicz, Wokół koligacji rodzinnych Ignacego Krasickiego z Sewerynem Rzewuskim, „Roczniki Humanistyczne” 50, 2002, z. 1, s. 62-63; J. Tretiak, Ignacy Krasicki. Charakterystyka..., s. 489; I. Krasicki, Krótki opis życia JO Ignacego hrabi Krasickiego, księcia arcybiskupa gnieźnieńskiego, [w:] L. Bernacki, Trzy biografie Ignacego Krasickiego, „Pamiętnik Literacki” 24-25, 1925-1926, s. 523.

27 J. Tretiak, Ignacy Krasicki. Charakterystyka..., s. 490.

28 E. Doktór, Krasicki nasz powszedni, Lublin 2011, s. 27; M. Piszczkowski, op. cit., s. 44.

29 J.I. Kraszewski, op. cit., s. 105.

30 J. Michalski, Sejm w czasach panowania Stanisława Augusta, [w:] Historia sejmu polskiego, red. J. Michalski, Warszawa 1984, s. 373.

31 W. Nehring, Studya literackie, Poznań 1884, s. 179-180.

32 I. Chrzanowski, Historja literatury niepodległej Polski (965-1795), Londyn 1947, s. 522. 
Do złożenia zaś homagium królowi Fryderykowi II w związku z przejściem jego diecezji pod panowanie pruskie wydelegował swojego biskupa pomocniczego, prusofila Karola Fryderyka von Zehmena ${ }^{33}$. Tragiczne perypetie konfederacji barskiej, zakończone rozbiorem Polski i wcieleniem Warmii do Prus we wrześniu 1772 roku, zadecydowały o ostatecznym zaniechaniu działalności polityczno-społecznej sensu stricto przez Krasickiego ${ }^{34}$.

Nie wziął on również udziału w radzie senatu w dniu 17 października 1772 roku, na której obecni senatorowie złożyli protest przeciwko postępowaniu trzech dworów sprzecznych z prawami i interesami Rzeczypospolitej. Nie stawił się również, jako senator, na posiedzeniu senatu w dniu 1 marca 1773 roku mimo osobistego wezwania króla Stanisława Augusta, na którym miano omawiać dalsze kroki związane z zachowaniem państw zaborczych ${ }^{35}$.

Wydarzeniom w dziejach Rzeczypospolitej w latach 1768-1772 miał okazję się trochę bliżej przyjrzeć i w nich uczestniczyć, ponieważ w tym czasie mieszkał w Warszawie (w pałacyku Konstancji Lelewelowej, przy ulicy Miodowej). Mimo wspomnianych możliwości „Krasicki w tym trudnym okresie wykazał brak sprężystości i orientacji politycznej”36.

Jednym z najbardziej znanych wydarzeń doby stanisławowskiej były słynne obiady czwartkowe regularnie zwłaszcza organizowane przez króla Stanisława Augusta w latach 1770-1777. Stanowily one swoisty salon literacki, miejsce spotkań intelektualistów polskich. Poruszano na nich nie tylko zagadnienia literackie czy kulturalne, ale także tematy poważniejsze, na przykład sprawy wagi państwowej ${ }^{37}$. Gwiazdą tychże spotkań, jeżeli tylko przebywał w Warszawie, był Krasicki. Niestety, jak zauważył nieżyczliwy jemu Teodor Ostrowski ${ }^{38}$, „Książę Biskup Warmiński bywa na literackich obiadach i zwyczajem swoim zabawia i rozrywa głęboko myślących literatów, zagadnieniami doświadcza, Króla Jmci bawi śmiesznymi powieściami, a czasem z daleka do swego interesu przymawia się"39.

Natomiast w dyskusji na temat spraw wagi państwowej Krasicki na ogół nie brał udziału, ustępując miejsca innym znanym uczestnikom obiadów, takim jak Hugo Kołłątaj, Ignacy Potocki, Stanisław Konarski, Adam Naruszewicz, Joachim Chreptowicz czy Grzegorz Piramowicz.

33 K. Stasiewicz, op. cit., s. 134.

34 M. Piszczkowski, op. cit., s. 45.

35 Z. Goliński, Kalendarz..., s. 404-405.

36 W. Maciąg, op. cit., s. 182-183. Zbigniew Goliński podaje, że Krasicki mieszkał w Warszawie do 1768 roku; idem, Kalendarz..., s. 288.

37 D. Kowalewska, Motywy paralelne autorów kręgu „Zabaw Przyjemnych i Pożytecznych” (na podstawie wybranych wierszy I. Krasickiego i A. Naruszewicza), „Acta Universitatis Nicolai Copernici. Nauki Humanistyczno-Społeczne. Filologia Polska” 15, 1995, z. 289, s. 4.

38 Teodor Ostrowski, historyk i prawnik, redagował w tym czasie „Gazetę Pisaną i Informacje Tygodniowe z Warszawy”, później był twórcą Prawa cywilnego narodu polskiego.

39 Z. Goliński, Kalendarz..., s. 579. 
Jego udanym debiutem literackim był Hymn do miłości Ojczyzny napisany w 1774 roku — ze względu bowiem na propagowane w nim idee patriotyczne stał się on hymnem Szkoły Rycerskiej, a każdy kadet musiał wyuczyć się go na pamięć $\dot{c}^{40}$.

Nie były mu również obojętne sprawy społeczne, które w tamtych czasach także miały wymowę polityczną. Na prośbę między innymi króla Stanisława $\mathrm{Au}-$ gusta Krasicki napisał w 1778 roku wiersz Mości książe Poniatowskit ${ }^{41}$, propagujący akt oczynszowania chłopów w dobrach Stanisława Poniatowskiego (bratanka królewskiego). Jego dobra w Korsuniu, w których przeprowadził on w 1777 roku reformę chłopską, objęły łącznie 400 tysięcy mieszkańców. Do sprawy będącej przedmiotem wspomnianego wiersza podszedł on jednak bez jakiegokolwiek emocjonalnego zaangażowania, traktując ją wyłącznie jako spełnienie prośby króla. Być może Stanisław August nieprzypadkowo zwrócił się ze wspomnianą prośbą do Krasickiego. Upamiętnił on bowiem wcześniej podobną reformę chłopską przeprowadzoną w 1764 roku przez Annę Jabłonowską ${ }^{42}$, o której w jednym z listów do Stanisława Poniatowskiego pisał: „Wszystkim chłopom, mieszczanom tego losu życzę, jaki mają Wysokie, Kock i Siematycze"43.

Nieobojętna była Krasickiemu również sprawa Kodeksu praw Andrzeja Zamoyskiego, mimo że sam osobiście nie był w nią zaangażowany, to jednak śledził losy tej niedoszłej do skutku kodyfikacji. Twórcy kodeksu usiłowali wciągnąć go $\mathrm{w}$ akcję propagandową z nim związaną ${ }^{44}$.

Szerzej Krasicki miał okazję przedstawić swoje poglądy polityczne, wydając w latach 1781-1783 Zbiór potrzebniejszych wiadomości porządkiem alfabetu ułożonych ${ }^{45}$, jedną z pierwszych polskich encyklopedii, inspirowaną dorobkiem francuskich encyklopedystów, których osobiście poznał, goszcząc w Paryżu. Krasicki w encyklopedii opowiedział się za modelem ograniczonej monarchii, zapobiegającej ,zarówno despotyzmowi, jak i nadmiernej wolności, z reguły zgubnej w skutkach". Świadczyło to o monteskiuszowskiej inspiracji jego poglądów

40 R. Stawicki, Dzieje Szkoły Rycerskiej - Korpusu Kadetów w latach 1765-1794, Warszawa 2015, s. 9. W notatce $O$ miłości ojczyzny i dobra publicznego opublikowanej 19 czerwca 1765 roku w „Monitorze” Krasicki podkreślał, że miłość ojczyzny cechuje wolne narody; Z. Goliński, Kalendarz..., s. 121.

41 Był to w zasadzie incipit, czyli wiersz niemający tytułu, a zaczynający się od wspomnianych słów; Z. Goliński, Kalendarz..., s. 532.

42 W. Pusz, Ignacy Krasicki i Stanisław Poniatowski. Wiersze do synowca króla i przyjaźn bez świadectw, „Prace Polonistyczne. Seria LXVIII” 2013, s. 150-151; F. Brodowski, Reforma włościańska 1864 r., Warszawa 1916, s. 8-9.

43 J. Bergerówna, Księżna Pani na Kocku i Siemiatyczach (działalność gospodarcza i społeczna Anny z Sapiehów Jabłonowskiej), Lwów 1936, s. 60; K.M. Górski, Pisma literackie z badań nad literatura polska XVII i XVIII wieku, Warszawa-Lublin-Łódź 1913, s. 342.

44 Z. Goliński, Kalendarz..., s. 575.

45 Wbrew przypisywanego Krasickiemu autorstwa encyklopedii nie tylko on był jej autorem. 
ustrojowych. Stanowisko to w pełni konweniowało z reformatorskim programem środowiska zamkowego króla Stanisława Augusta ${ }^{46}$.

Krasicki pojawił się w Warszawie jesienią 1782 roku, po sejmie, który obradował od 30 września do 9 listopada 1782 roku i który po długich, rozwlekłych, rozgadanych i bezowocnych obradach został określony jako „najgłupszy, jaki się kiedykolwiek odbył od czasu politowania godnej pamięci Jana Kazimierza" ${ }^{\text {"7 }}$. Był to jeden z dwóch sejmów (drugi miał miejsce w 1786 roku), na którym ujawniła się bardzo mocno linia podziałów politycznych wśród obradujących posłów. Głównym przedmiotem obrad tego sejmu stało się oskarżenie przez opozycję antykrólewską Stanisława Augusta Poniatowskiego i Rady Nieustającej o złamanie prawa neminem captivabimus przy ubezwłasnowolnieniu umysłowo chorego biskupa Kajetana Sołtyka, po usunięciu którego dochody z biskupstwa krakowskiego przejął brat królewski Michał Poniatowski ${ }^{48}$.

Swoją reakcję na coraz bardziej brutalną ingerencję Rosji w wewnętrzne sprawy Polski Krasicki zawarł w końcu pieśni drugiej Wojny chocimskiej opublikowanej w 1780 roku, pisząc w niej:

\footnotetext{
Naród monarsze choć władzy powierzył,

Wraz z nim na tronie wolność odpoczywa;

Tą blask rażący łagodnie uśmierzył.

Żeby zaś zbytkiem nie była szkodliwa,

Prawem tak wspólne granice wymierzył,

Że tron go zdobi, a wolność okrywa,

Król wolnych kocha, naród sobie godny,

Swóy wybór w królu szanuje swobodny.
Z trzech stanów całość powszechna się składa, Wszystkie trzy razem wzajem silą się i ważą:
Król pierwsze mieysce na tronie osiada,
Senat swobodny ma kraju pod strażą,
Rycerstwo równie losem kraju włada;
Wszystkie trzy, kiedy uradzą i każą.
Co każą razem: król, bracia, starszyzna,
To każe naród, to mówi oyczyzna.

W pieśni tej, jak widzimy, zawarł Krasicki pochwałę dotychczasowej konstytucji Rzeczypospolitej, ze szczególnym uwielbieniem „złotej wolności”. Zawarł w niej wizerunek ustawy obowiązującej naród polski zupełnie podobny do tego ustroju wewnętrznego Polski, jaki królowi i sejmowi pod laską Adama Ponińskiego

46 A.F. Grabski, ,Encyklopedia uniwersalna Księcia Biskupa Warmińskiego i jej rola w edukacji obywatelskiej czasów stanisławowskich”, Irena Stasiewicz-Jasiukowa, Warszawa 1994, „Kwartalnik Historii Nauki i Techniki” 39, 1994, nr 3-4, s. 171.

47 Z. Goliński, „Postawa ideowa Ignacego Krasickiego po roku 1780”. Roman Wołoszyński, Wroctaw 1953, „Pamiętnik Literacki” 45, 1954, z. 3, s. 328.

48 A. Stroynowski, Sejmowa opozycja antykrólewska w czasach rządów Rady Nieustającej (kryteria klasyfikacji), „Acta Universitatis Lodziensis. Folia Historica” 18, 1984, s. 24-25. 
zebranemu w 1773 roku narzucony został, a wyrażający się przede wszystkim w ustanowieniu Rady Nieustającej. Krasicki, wychwalając wcześniejszą wolność, nie mówił w tym przypadku jako biskup warmiński niemający wstępu do Rady Nieustającej, ale przemawiał w duchu tych, którzy wolność w Polsce utrzymać i utrwalić chcieli, aby kraj z niemocy się wydosta ${ }^{49}$. Jest to jeden z nielicznych fragmentów utworów Krasickiego, w którym tak bezpośrednio odniósł się do ustroju Rzeczypospolitej i prób jego zmiany.

Każdy widzi to, co sam chciałby zobaczyć. Stanisław August bowiem w Wojnie chocimskiej widział bohaterski poemat sławiący czyny oręża polskiego i wojnę z Turcją. Będący o tyle na czasie, że zbiegający się z jego planami ewentualnego sojuszu z Rosją przeciw Porcie Otomańskiej ${ }^{50}$.

W sierpniu 1784 roku z misją od króla — do Krasickiego w Lidzbarku Warmińskim — przybył Stanisław Trembecki, usiłując nakłonić go do poparcia planów politycznych władcy dotyczących przymierza polsko-rosyjskiego w wojnie z Turcją w zamian za zgodę Katarzyny II na reformy w Polsce. Krasicki, mimo że żywo interesował się aktualnymi wydarzeniami w kraju, unikał angażowania się w politykę. Konsekwentnie przyjmując od początku lat osiemdziesiątych XVIII wieku jedynie postawę obserwatora wydarzeń politycznych rozgrywających się w kraju ${ }^{51}$.

Rozpoczęcie obrad przez Sejm Czteroletni w 1788 roku nie za bardzo zainteresowało Krasickiego. Przybył do Warszawy po kilku latach nieobecności, dopiero 4 lipca 1789 roku. I to nie w celu, by wziąć udział w pracach Sejmu Wielkiego, lecz w związku ze staraniami o objęcie biskupstwa krakowskiego ${ }^{52}$. Pragnął nominacji na to stanowisko, ale nie za cenę zaangażowania się w reformy sejmu, a nawet w dyskusję o nich. Nie spodziewał się bowiem w tym okresie żadnych istotnych i trwałych sukcesów wynikających z obrad. Gdy nic z tych planów nie wyszło, po trzech tygodniach opuścił Warszawę na stałe. O wypadkach sejmowych z czasów Sejmu Czteroletniego nie ma żadnej wzmianki w jego listach, mimo że zawsze prowadził on obszerną korespondencję $\mathrm{z}$ różnymi osobami ${ }^{53}$. Odbiły się one jedynie słabym echem w jego pismach, głównie bajkach ${ }^{54}$.

Jednym z nielicznych przykładów jego zainteresowania ówczesnymi sprawami polskimi była surowa ocena ewentualnego aliansu politycznego Polski

49 W. Nehring, op. cit., s. 227.

50 M. Piszczkowski, op. cit., s. 381.

51 B. Mazurkowa, Gorzki obrachunek Ignacego Krasickiego u progu sejmu grodzieńskiego 1784 roku, [w:] eadem, Z potrzeby chwili i ku pamięci... Studia o poezji i prozie oświecenia, Warszawa 2019, s. 75-76.

52 Por. na ten temat R. Butterwick, ,Intrighi e simonie”. Wokól biskupstwa krakowskiego w 1789 roku, „Kwartalnik Historyczny” 111, 2004, nr 4, s. 103-126.

53 J.I. Kraszewski, op. cit., s. 282, 296, 320; K. Wojciechowski, Ignacy Krasicki, LwówWarszawa-Kraków 1922, s. 143; W. Maciąg, op. cit., s. 330-331.

54 A.M. Kurpiel, Polityczne i społeczne przekonania I. Krasickiego, Jarosław 1896, s. 19. 
z Prusami oraz nadziei, jakie w związku z tym niektórzy polscy politycy pokładali ${ }^{55}$. Ambasador pruski w Warszawie Girolamo Lucchesini zwodził Polaków, że przy pomocy Prus łatwo da się przeprowadzić reformę polityczną i przywrócić Polsce stanowisko niezależnego państwa. Krasicki, po przyjeździe w tym czasie do Warszawy, od razu niezwykle trzeźwo przeniknął wszystkie słabe strony tego aliansu politycznego. Wyszydzał układy z posłem pruskim, porównując sejmujące stany z organami, na których przygrywa Lucchesini ${ }^{56}$. Była to opinia człowieka niewątpliwie świadomego.

Bardzo pozytywnie ocenił natomiast Krasicki przyjętą w tym czasie jednomyślnie uchwałę sejmu o stutysięcznym wojsku ${ }^{57}$.

„Bezkrwawą rewolucję”, jaką było uchwalenie Konstytucji 3 maja, Krasicki przyjął z właściwą powagą doniosłości tego momentu w dziejach Polski, czcząc jej uchwalenie dwoma epigramatami ${ }^{58}$, a z okazji uroczystości pierwszej rocznicy uchwalenia Ustawy Rządowej, w których jednakże osobiście nie brał udziału, skomponował Pieśń na 3 Maja roku $1792^{59}$, na melodię zapożyczoną z pieśni Do Ciebie, Panie, wznosim nasze modty. Odśpiewało ją duchowieństwo warszawskie podczas procesji wiodącej z kościoła świętego Krzyża do ogrodu Ujazdowskiego, gdzie położono kamień węgielny pod kościół Opatrzności ${ }^{60}$. Była to jedyna forma jego aktywności o charakterze patriotycznym związana z dokonaniami Sejmu Wielkiego, której wymowę osłabia niestety fakt, że wspomniany Hymn napisał on na żądanie króla Stanisława Augusta ${ }^{61}$. Natomiast znawcy twórczości Krasickiego podkreślają, że utwór ten był ,blady, zimny, świadczący, że ani wiary w powodzenie, ani zapału patriotycznego w Krasickim nie było"62.

55 J.I. Kraszewski, op. cit., s. 295.

56 J. Tretiak, Ignacy Krasicki. Charakterystyka..., s. 512; T. Korzon, Historya Polski, Kijów 1918, s. 291. O stosunku Krasickiego do tego aliansu politycznego nic natomiast nie wspomina Szymon Askenazy; idem, Przymierze polsko-pruskie, Warszawa 1918.

57 J. Tretiak, Ignacy Krasicki. Charakterystyka..., s. 513.

58 Epigramat — krótki utwór poetycki w formie aforyzmu. Jeden z nich odlany w brązie został umieszczony w zamku warszawskim; J.T. Pokrzywniak, Ignacy Krasicki. Wśród pisarzy polskiego oświecenia, Poznań 2016, s. 360. Wojciech Szczygielski pisze natomiast, że był on umieszczony na tablicy marmurowej także w zamku warszawskim; idem, Sejm Wielki (1788-1792). Studium $z$ dziejów lagodnej rewolucji, Łódź 2015, s. 57. Być może był to drugi ze wspomnianych epigramów Krasickiego.

59 I. Krasicki, Pieśń Na 3. Dzień Maia Roku 1792, Warszawa 1792. Spotykany jest także tytuł: Hymn na rocznice 3-go Maja, [w:] Trzeci Maj. Ku uczczeniu setnej rocznicy Konstytucyi Trzeciego Maja 1791-1891, Poznań 1891, s. 118.

60 K. Maksymowicz, op. cit., s. 65-66; J.T. Pokrzywniak, op. cit., s. 363; Z. Goliński, Ignacy Krasicki o Sejmie i Konstytucji 3 Maja, [w:] „,Rok Monarchii Konstytucyjnej”. Piśmiennictwo polskie lat 1791-1792 wobec Konstytucji 3 Maja, red. T. Kostkiewiczowa, Warszawa 1992, s. 68-72.

61 J.I. Kraszewski, op. cit., s. 320.

62 J. Tretiak, Ignacy Krasicki. Charakterystyka ..., s. 517; I. Chrzanowski, Historja ..., s. 466. 
Krasicki został członkiem konfederacji Sejmu Czteroletniego, mimo że nie był stronnikiem jego polityki ${ }^{63}$.

Ród Krasickich, mimo powiązań rodzinnych z Sewerynem Rzewuskim i Szczęsnym Potockim oraz wbrew rysującym się przed nim korzyściom, pozostał lojalny wobec Rzeczypospolitej, odrzucając propozycję przejścia do opozycji antykrólewskiej i przyłączenia się do targowicy w 1792 roku. Niewątpliwie wpływ na tę decyzję miała opinia Krasickiego, na zamku którego w Lidzbarku Warmińskim odbyła się „narada klanu Krasickich” w tej tak ważnej sprawie ${ }^{64}$.

Krasicki nie zapomniał również o Konstytucji 3 maja, składając we wrześniu 1793 roku Michałowi Gröllowi (u którego najczęściej drukował swoje utwory) przygotowany przez siebie Kalendarz obywatelski na rok 1794, w którym mimo tego, że było to oficjalnie przez targowicę zabronione, zawarł informacje o uchwałach Sejmu Wielkiego ${ }^{65}$.

Do insurekcji kościuszkowskiej odniósł się w alegorycznej przypowieści o dziejach Polski opublikowanej w czerwcu 1794 roku (Powieść prawdziwa o narożnej kamienicy w Kukorowcach), zakończonej wezwaniem do walki o niepodległość 66 . Było to jednak zdecydowanie za mało w stosunku do tego, czego od niego oczekiwano.

W twórczości Krasickiego nie znajdujemy także żadnych śladów głębszego przejęcia się upadkiem Rzeczypospolitej w 1795 roku. Brakło mu dawnej pasji i osobistego zaangażowania, a być może po prostu się zestarzał ${ }^{67}$.

Jak zauważył ponad 120 lat temu Antoni Marian Kurpiel:

pisać o politycznych zapatrywaniach i przekonaniach Krasickiego było rzeczą dość niewdzięczną. Spodziewać by się należało, że w epoce ogólnego przewrotu politycznego, że wobec rozmaitych, wtedy powstałych teorii, z jednej strony, popieranych zawzięcie, z drugiej, zawzięcie zwalczanych, Krasicki także w tych sprawach głos poważny zabierze.

Tymczasem nie zamierzał on wbrew oczekiwaniom tego robić, nie chciał bawić się teoriami politycznymi. Krasicki mimo to nie był politykiem-statystą, politykomanii nie lubił i wyśmiewał ją. Głosił przy tym przekonanie, że „obywatel powinien stronić od »politycyzmu«. Politycyzm, według niego, był »febrą periodyczną, na którą trudno było o lekarstwo, a jeżeli się znachodzą, to kto wie, czy takie, jakich potrzeba, choć lekarzów dość«"68.

63 G.E., Juliana Bartoszewicza. Historya literatury polskiej, potocznym sposobem opowiedziana, Warszawa 1861, „Biblioteka Warszawska” 1, 1861, s. 408-409.

${ }^{64}$ K. Maksymowicz, op. cit., s. 68; Z. Goliński, Ignacy Krasicki, s. 383-384.

65 I. Krasicki, Kalendarz obywatelski, Lwów 1794, s. 25; J.T. Pokrzywniak, op. cit., s. 365; Z. Goliński, Ignacy Krasicki, s. 387.

66 Z. Goliński, Krasicki..., szp. 148.

67 R. Wołoszyński, op. cit., s. 42.

68 A.M. Kurpiel, op. cit., s. 1-2. Być może poglądy Krasickiego w tym zakresie ukształtowały się pod wpływem jego pierwszego mentora, prymasa Łubieńskiego, który podobnie krytycznie oceniał polityków, a wszelkie ich fakcje były dla niego tożsame z intrygą oraz szkodliwe dla państwa; 
Będąc senatorem Rzeczypospolitej i rządcą jednego z najważniejszych biskupstw polskich, Krasicki mógł odgrywać niewątpliwie znacznie większą rolę w życiu politycznym Polski doby stanisławowskiej, niż miało to miejsce. Mimo że był senatorem zobligowanym do brania udziału w posiedzeniach sejmu, nawet w jego pracach bardzo szybko przestał brać aktywny udział ${ }^{69}$. Mężem czynu bowiem Krasicki nigdy nie był. W sprawach politycznych, nawet w obliczu rozkazów króla, żadnej roli nie odegrał i nie chciał odgrywać. Nie dlatego, że na polityce się nie znał (przeciwnie, znał się na niej dobrze), ale z tego względu, że jej po prostu nie cierpiał. Działalność polityczna, jego zdaniem, mąciła człowiekowi pogodę ducha, nie pozwalała mu zażywać wygody i swobody, które Krasicki kochał i cenił ponad wszystko ${ }^{70}$. Stanisław August bardzo się pomylił co do jego osoby, gdy planował uczynić go jednym z filarów stronnictwa dworskiego.

Czas panowania Stanisława Augusta Poniatowskiego można podzielić na dwa podokresy charakteryzujące stosunek Krasickiego do zaistniałych wydarzeń politycznych — do połowy lat osiemdziesiątych XVIII wieku i po nim. W pierwszym okresie, od roku 1765, szczególnie zaś w latach 1773-1784, Krasicki nakazał sobie swoistą służbę narodową, podporządkowując także swoje pisarstwo celom publicznym, i obracał się w kręgu problemów zakreślonych przez polskie środowisko, reform ustroju państwowego i społecznego ${ }^{71}$. Jak widzimy, okres ten pokrywa się z ukazywaniem się „Monitora”.

W drugim — od połowy lat osiemdziesiątych XVIII wieku do końca jego życia - można zauważyć regres w jego twórczości. Odtąd u Krasickiego nasiliły się akcenty pesymizmu i zwątpienia, jeśli idzie o sprawy publiczne. Szczególnie odrzucenie przez sejm w 1780 roku kodeksu Zamoyskiego wywarło na nim przygnębiające wrażenie ${ }^{72}$. Nie wierzył także w skuteczność działań Sejmu Czteroletniego oraz powodzenie powstania Kościuszki ${ }^{73}$. W okresie tym wydawał się on pozornie oziębły i obojętny na sprawy publiczne. Przyjął postawę Horacego - satyryka, w ramach której starał trzymać się zasady złotego środka, mierności i doskonałej izolacji od burzliwych, niepokojących i niebezpiecznych kluczowych spraw tej epoki. Z jego poufnych listów z tego okresu wyłania się jednak obraz człowieka, który mocno odczuwał nieszczęścia kraju, jakim niestety nie dało się przeciwdziałać 74 .

K. Kuras, Partie i fakcje w schyłkowym okresie rządów Augusta III Sasa, „Przegląd Nauk Historycznych" 12, 2013, nr 1, s. 67.

${ }^{69} \mathrm{~W}$ literaturze spotykane są także odwrotne opinie, że mało przebywał w Heilsbergu (Lidzbarku Warmińskim), stolicy biskupstwa warmińskiego, a czas przepędzał przeważnie w Warszawie, gdzie jako senator brał udział w radzie królewskiej i na sejmach; F. Łagowski, Ignacy Krasicki i jego dzieła w setna rocznice, Warszawa 1902, s. 9.

${ }^{70}$ I. Chrzanowski, Historja ..., s. 465.

71 R. Wołoszyński, op. cit., s. 18-19.

72 Ibidem, s. 39.

73 I. Chrzanowski, Historja..., s. 466.

74 J.I. Kraszewski, op. cit., s. 321; R. Wołoszyński, op. cit., s. 40. 
Jako pisarz pozostawał Krasicki jednym z najpracowitszych i najzdolniejszych polskich autorów, jako duchowny był typowym przedstawicielem hierarchii kościelnej tamtych czasów, natomiast w kontekście działań politycznych wyłania się obraz człowieka, który zawiódł oczekiwania z nim związane ${ }^{75}$.

Zdaniem Konstantego Wojciechowskiego Krasicki przez całe życie trwał na stanowisku apolitycznym, a nie obojętnym wobec tego, co się działo w ówczesnej Polsce. Uznawał on potrzebę reform, ale o umiarkowanym charakterze ${ }^{76}$. Ze zwolennikami zmian łączyło go to, iż uświadamiał sobie, że przed Polską stoją dwa zadania: dogonić Europę i pozostać sobą. Umysł jego jednak, mimo że, zdaniem Juliusza Kleinera, jasny, nie pojmowal, że zrównanie z Zachodem i obrona własnej odrębności są zagadnieniami ustrojowymi. Rozumieli i pojmowali to natomiast Stanisław August Poniatowski, Stanisław Staszic czy Hugo Kołłątaj ${ }^{77}$.

Nie wierząc w przyszłość Polski jako państwa, nie wątpił jednak Krasicki w jej przyszłość jako narodu. Utyskując nierzadko na wiek XVIII, w którym przyszło mu żyć, Krasicki nie tylko wzdychał do lepszej, renesansowej przeszłości Polski, lecz równocześnie wybiegał myślą ku utopijnej — jak czas pokazał — nowej jej wizji ${ }^{78}$.

W 1795 roku, po rozbiorach Polski, został arcybiskupem gnieźnieńskim. Zmarł 14 marca 1801 roku w Berlinie.

\section{Bibliografia}

Achremczyk S., Nowa biografia Ignacego Krasickiego, „Komunikaty Mazursko-Warmińskie” $1980, \mathrm{nr} 2$.

Aleksandrowska W., Problemy monitorowego autorstwa Krasickiego. Z warsztatu bibliografa „,Monitora”, „Pamiętnik Literacki” 90, 1999, z. 1.

Askenazy S., Przymierze polsko-pruskie, Warszawa 1918.

Bergerówna J., Księżna Pani na Kocku i Siemiatyczach (działalność gospodarcza i społeczna Anny z Sapiehów Jabłonowskiej), Lwów 1936.

Brodowski F., Reforma włościańska 1864 r., Warszawa 1916.

Butterwick R., ,Intrighi e simonie”. Wokót biskupstwa krakowskiego w 1789 roku, „Kwartalnik Historyczny" 111, 2004, $\mathrm{nr} 4$.

Chrzanowski I., Historja literatury niepodległej Polski (965-1795), Londyn 1947.

Chrzanowski I., Krasicki jako autor Monitora z roku 1772, „Pamiętnik Literacki” 3, 1904, z. 2.

Doktór E., Krasicki nasz powszedni, Lublin 2011.

Dygdała J., Adam Stanisław Grabowski (1698-1766). Biskup, polityk, mecenas, Olsztyn 1994.

Dygdała J., Życie polityczne Prus Królewskich u schyłku ich związu z Rzeczapospolita w XVIII wie$k u$, Warszawa-Poznań-Torun 1984.

75 M. Piszczkowski, op. cit., s. 475.

76 K. Wojciechowski, op. cit., s. 165-166.

77 J. Kleiner, Ignacy Krasicki, [w:] Zjazd Naukowy Imienia Ignacego Krasickiego we Lwowie w dniach 8-10 czerwca 1935 roku. Księga referatów, red. L. Bernacki, Lwów 1936, s. 253-254.

78 M. Piszczkowski, op. cit., s. 472; I. Chrzanowski, Historja ..., s. 523. 
G.E., Juliana Bartoszewicza. Historya literatury polskiej, potocznym sposobem opowiedziana, Warszawa 1861, „Biblioteka Warszawska” 1, 1861.

Goliński Z., Ignacy Krasicki, Warszawa 1979.

Goliński Z., Ignacy Krasicki o Sejmie i Konstytucji 3 Maja, [w:] „, Rok Monarchii Konstytucyjnej”. Piśmiennictwo polskie lat 1791-1792 wobec Konstytucji 3 Maja, red. T. Kostkiewiczowa, Warszawa 1992.

Goliński Z., Kalendarz życia i twórczości Ignacego Krasickiego, Poznań 2011.

Goliński Z., Krasicki Ignacy Błażej Franciszek h. Rogala, [w:] Polski Słownik Biograficzny, t. 15. Kozłowska Zofia-Kubacki Stanisław, Wrocław-Warszawa-Kraków 1970.

Goliński Z., „Postawa ideowa Ignacego Krasickiego po roku 1780”. Roman Woloszyński, Wroctaw 1953, „Pamiętnik Literacki” 45, 1954, z. 3.

Gombin K., Lwów w ceremoniale Trybunału Koronnego prowincji małopolskiej, „Annales Universitatis Mariae Curie-Skłodowska. Sectio L" 8, 2010, nr 2.

Górski K.M., Pisma literackie z badań nad literatura polska XVII $i$ XVIII wieku, Warszawa-Lublin-Łódź 1913.

Grabski A.F., „Encyklopedia uniwersalna Księcia Biskupa Warmińskiego i jej rola w edukacji obywatelskiej czasów stanisławowskich”, Irena Stasiewicz-Jasiukowa, Warszawa 1994, „Kwartalnik Historii Nauki i Techniki" 39, 1994, nr 3-4.

Grużewski B., Napad na prezydenta Trybunału (Rok 1765). Przyczynek biograficzno-obyczajowy $z$ drugiej polowy XVIII wieku, [w:] Pamiętnik trzydziestolecia pracy naukowej prof. dr. Przemystawa Dąbkowskiego, Lwów 1927.

Kleiner J., Ignacy Krasicki, [w:] Zjazd Naukowy Imienia Ignacego Krasickiego we Lwowie w dniach 8-10 czerwca 1935 roku. Księga referatów, red. L. Bernacki, Lwów 1936.

Klimowicz M., Oświecenie, Warszawa 1975.

Korzon T., Historya Polski, Kijów 1918.

Kowalewska D., Motywy paralelne autorów kręgu „Zabaw Przyjemnych i Pożytecznych” (na podstawie wybranych wierszy I. Krasickiego i A. Naruszewicza), „Acta Universitatis Nicolai Copernici. Nauki Humanistyczno-Społeczne. Filologia Polska" 45, 1995, z. 289.

Krasicki I., Hymn na rocznicę 3-go Maja, [w:] Trzeci Maj. Ku uczczeniu setnej rocznicy Konstytucyi Trzeciego Maja 1791-1891, Poznań 1891.

Krasicki I., Kalendarz obywatelski, Lwów 1794.

Krasicki I., Krótki opis życia JO Ignacego hrabi Krasickiego, księcia arcybiskupa gnieźnieńskiego, [w:] L. Bernacki, Trzy biografie Ignacego Krasickiego, „Pamiętnik Literacki”24-25, 1925-1926.

Krasicki I., Pieśń Na 3. Dzień Maia Roku 1792, Warszawa 1792.

Kraszewski J.I., Krasicki. Życie i dzieła. Kartka z dziejów literatury XVIII wieku, Warszawa 1879.

Kraushar A., Ksią̇ę Repnin a Polska w pierwszem czteroleciu panowania Stanisława Augusta (1764-1768), t. 2, Kraków 1898.

Kuras K., Partie i fakcje w schytkowym okresie rządów Augusta III Sasa, „Przegląd Nauk Historycznych" 12, 2013, nr 1.

Kurpiel A.M., Polityczne i społeczne przekonania I. Krasickiego, Jarosław 1896.

Łagowski F., Ignacy Krasicki i jego dzieła w setna rocznice, Warszawa 1902.

Maciąg W., Życie Ignacego Krasickiego. Zapisy i domysty, Warszawa 1984.

Maksymowicz K., Wokót koligacji rodzinnych Ignacego Krasickiego z Sewerynem Rzewuskim, „Roczniki Humanistyczne” 50, 2002, z. 1.

Mayer Z., Wizerunek Trybunału Koronnego. Studjum prawno-obyczajowe, Lwów 1929.

Mazurkowa B., Gorzki obrachunek Ignacego Krasickiego u progu sejmu grodzieńskiego 1784 roku, [w:] eadem, Z potrzeby chwili i ku pamięci... Studia o poezji i prozie oświecenia, Warszawa 2019.

Michalski J., Sejm w czasach panowania Stanisława Augusta, [w:] Historia sejmu polskiego, red. J. Michalski, Warszawa 1984.

Nehring W., Studya literackie, Poznań 1884. 
Parkitny M., O genezie „Myszeidy” Ignacego Krasickiego, „Pamiętnik Literacki” 89, 1998, z. 1.

Pilarczyk P.M., Doświadczyński przed Trybunatem. Twórczość Ignacego Krasickiego w świetle historii prawa, „Pamiętnik Literacki” 118, 2017, z. 3.

Piszczkowski M., Ignacy Krasicki. Monografia literacka, Kraków 1975.

Pusz W., Ignacy Krasicki i Stanisław Poniatowski. Wiersze do synowca króla i przyjaźń bez świadectw, „Prace Polonistyczne. Seria LXVIII” 2013.

Pokrzywniak J.T., Ignacy Krasicki. Wśród pisarzy polskiego oświecenia, Poznań 2016.

Stasiewicz K., Obywatelskie dylematy uśmiechniętego biskupa Ignacego Krasickiego, „Komunikaty Mazursko-Warmińskie" 2018, nr 1.

Stawicki R., Dzieje Szkoły Rycerskiej - Korpusu Kadetów w latach 1765-1794, Warszawa 2015.

Stroynowski A., Sejmowa opozycja antykrólewska w czasach rząów Rady Nieustającej (kryteria klasyfikacji), „Acta Universitatis Lodziensis. Folia Historica” 18, 1984.

Szczygielski W., Sejm Wielki (1788-1792). Studium z dziejów łagodnej rewolucji, Łódź 2015.

Tretiak J., Ignacy Krasicki. Charakterystyka w ramach szkicu biograficznego, „Biblioteka Warszawska" 4, 1901.

Tretiak J., Ignacy Krasicki jako prezydent trybunału, Kraków 1895.

Wojciechowski K., Ignacy Krasicki, Lwów-Warszawa-Kraków 1922.

Wołoszyński R., Ignacy Krasicki a myśl oświecenia, „Pamiętnik Literacki” 61, 1970, z. 2.

Zaleski J., Panowanie Stanisława Augusta do czasu Sejmu Czteroletniego, Poznań-Kraków 1887.

\title{
Bishop Ignacy Krasicki's attitude to the political-legal reforms in Poland of the King Stanisław era
}

\begin{abstract}
Summary
Bishop Ignacy Krasicki was one of the best known figures in Poland of the King Stanisław era. He was known primarily as a poet, writer, author of fables. As the Bishop of Warmia, he occupied a very high position in Poland's political hierarchy at the time - he was a member of the country's Senate. Yet, he failed to meet the expectations of the people associated with him, primarily King Stanisław August Poniatowski, whose closest associates included Krasicki in the first period of his political career. His involvement after 1772, the most important time in the analysed period with regard to political-legal reforms in Poland, was made difficult by the fact that the Bishopric of Warmia, which he was the head of, found itself outside Poland's borders, an event not without an impact on Krasicki's political attitude. Krasicki not being much involved in the turbulent political life in Poland at the time does not mean that Poland's affairs were not close to his heart. He was first and foremost a poet, not a politician, and that is why he referred to these affairs metaphorically in his literary works.
\end{abstract}

Keywords: Bishop Ignacy Krasicki, Bishopric of Warmia, King Stanisław era, Monitor, political-legal reforms, Stanisław August Poniatowski. 


\title{
Die Stellung von Bischof Ignacy Krasicki $\mathrm{zu}$ den rechtlichen und politischen Reformen in Polen der Poniatowskizeit
}

\author{
Zusammenfassung
}

Der Bischof Ignacy Krasicki war eine der bekanntesten Personen in Polen der Poniatowskizeit, bekannt vor allem als Dichter, Literat und Märchenschreiber. Als Bischof von Ermland und Mitglied des Senats hatte er auch eine sehr hohe Position in der damaligen politischen Hierarchie in Polen. Entgegen den Erwartungen der ihm nahe stehenden Personen, vor allem des Königs Stanislaus II. August Poniatowski, zu dessen engsten Mitarbeitern er in der ersten Phase seiner eigenen politischen Kariere gehörte, erfüllte er die an ihn gesetzten Hoffnungen nicht. Sein Engagement nach 1772, also dem wichtigsten Jahr in der besprochenen Zeit hinsichtlich der rechtlichen und politischen Reformen in Polen, war erschwert. Das Bistum Ermland, das er verwaltete, kam nämlich außerhalb der Grenzen von Polen, was nicht ohne Einfluss auf seine politische Haltung blieb. Das gemäßigte Engagement Krasickis in das rege politische Leben in Polen soll nicht so gedeutet werden, dass dieses Thema ihn nicht berührte. Er war vor allem ein Dichter und kein Politiker, so äußerte er sich zu den polnischen Angelegenheiten per Metaphern in seinen literarischen Werken.

Schlüsselwörter: Bischof Ignacy Krasicki, Bistum Ermland, Poniatowskizeit, Wochenschrift „Monitor”, politische und rechtliche Reformen, Stanislaus II. August Poniatowski. 